\title{
Зиборов Д.В. \\ Развитие туризма в Северо-Кавказском федеральном округе: перспективы и проблемы
}

ФГБОУ ВО "Пятигорский государственный университет" (ПГУ) (Россия, Пятигорск)

doi: $10.18411 / \mathrm{lj}-06-2021-271$

\section{Аннотация}

В статье проводится анализ возможностей для развития туризма в СевероКавказском федеральном округе. Рассматриваются природные, географические, климатические и культурные факторы, которые могут положительно повлиять на развитие туристической отрасли в регионе. Делается вывод, что большой потенциал региона остаётся во многом нереализованным.

Ключевые слова: Россия, туризм, Северный Кавказ.

\section{Abstract}

The article analyzes the opportunities for tourism development in the North Caucasus Federal District. Natural, geographical, climatic and cultural factors that can positively influence the development of the tourism industry in the region are considered. It is concluded that the great potential of the region remains largely unrealized.

Keywords: Russia, tourism, North Caucasus.

Туризм в мире с каждым годом становится всё популярнее. Причин тому несколько: удешевление авиаперелётов (появление компаний-лоукостеров), достижения научно-технического прогресса, позволяющие туристам забронировать номер, не выходя из дома, возможность поделиться своими впечатлениями в социальных сетях. В России туризм составляет лишь малую часть общего ВВП, однако развитие этой сферы может благотворно повлиять на социально-экономические показатели туристических городов и регионов.

Проанализируем особенности развития туриндустрии в Северо-Кавказском федеральном округе. В СКФО входят 7 субъектов Российской Федерации: Республика Дагестан, Республика Ингушетия, Кабардино-Балкарская Республика, КарачаевоЧеркесская Республика, Республика Северная Осетия - Алания, Чеченская Республика, Ставропольский край. Каждый регион имеет свои этнокультурные, экономические и политические особенности. Можно сказать, что СКФО представляет собой «лоскутное одеяло», где переплелись несколько уникальных по своим характеристикам регионов.

Тем не менее, мы попробуем выделить общие черты, которые позволили бы нам говорить об СКФО как о едином туристическом макрорегионе.

Ещё начиная с XIX века Северный Кавказ был местом, куда приезжали отдохнуть и поправить здоровье представители дворянской элиты Российской империи. Их привлекал мягкий климат, живописные горные пейзажи и целебные минеральные источники. Начиная со времён Кавказской войны и экспансии Российской империи в регионе, Кавказские минеральные воды стали региономгоспиталем, где солдаты, раненые в боях, восстанавливали здоровье.

В период советской власти проводилась массовая кампания по популяризации туризма. Тогда же начался и бурный рост туристической инфраструктуры. Строились санатории, железные дороги, парки.

В настоящее время Северо-Кавказский регион, безусловно, можно считать одним из основных туристский кластеров нашей страны. Здесь есть и горнолыжные трассы, и санаторно-курортные СПА-комплексы, и маршруты для экстремального туризма. 
Одним из преимуществ СКФО как туристско-рекреационного кластера является природно-климатический фактор. Южный мягкий климат и чистый воздух привлекают гостей со всей России. В году преобладают солнечные дни, а осадков выпадает немного. При этом в горных районах снежный покров задерживается продолжительное время, что делает возможным долгий горнолыжный сезон.

В СКФО расположено множество памятников природы. К примеру, гора Эльбрус - высшая точка Европы (5642 м.), горы-лакколиты Кавказских Минеральных Вод, живописные ущелья и водопады, минеральные источники, ледники, реликтовые леса. Также в регионе расположено большое количество особо охраняемых природных территорий (ООПТ). На сегодняшний день самой большой по территории и старейшей ООПТ является Кавказский государственный природный биосферный заповедник имени Х. Г. Шапошникова.

Помимо ООПТ регион отрывает широкие возможности для пешего туризма и альпинизма. Популярные пешие маршруты привлекают туристов со всей страны и из-за границы. Нетронутая природа, дикие ущелья, бурные горные реки - всё это представляет собой идеальную основу для экотуризма, приключенческого и экстремального туризма. Можно говорить о развитии рафтинга, скалолазания, спелеотуризма, каньонинга, бейс-джампинга, парапланеризма и многих других видов экстремального спорта и активного отдыха.

Также нельзя не упомянуть горнолыжный потенциал региона. На территории СКФО действует несколько крупных горнолыжных курортов.

Говоря о культурно-историческом аспекте развития туризма, можно отметить, что СКФО имеет здесь колоссальный потенциал. Северный Кавказ издавна был регионом, где пересекаются множество народов и культур. Кавказ, находясь на границе между Востоком и Западом, впитывает в себя черты Европейской и Азиатской цивилизации. Здесь встречались разные языки, обычаи, традиции, религии, кухни.

Говоря о материальном наследии, важно подчеркнуть, что именно в СКФО находятся уникальные памятники древности. Пожалуй, одним из известнейших памятников истории является город Дербент. Цитадель, Старый город и крепостные сооружения Дербента - одна из немногих достопримечательностей в России, которая входит в список Всемирного наследия ЮНЕСКО.

Архитектура более позднего периода представлена сооружениями коренных кавказских народов. Так, сторожевые родовые башни, дошедшие до наших дней, являются жемчужиной военной и гражданской архитектуры тех времен. Они расположены по всему СКФО: на территории Осетии, Дагестана, Ингушетии, Чечни и Кабардино-Балкарии.

Особенно большую роль в туристическом потенциале СКФО играет регион Кавказских минеральных вод (КМВ). Регион КМВ является рекреационным центром федерального уровня. Здесь находятся такие города-курорты как Ессентуки, Железноводск, Кисловодск, Пятигорск, которые традиционно считаются всероссийскими здравницами. Регион имеет развитую санаторно-курортную инфраструктуру, уникальные бальнеологические ресурсы, большой природногеографический потенциал и благоприятный для оздоровительного отдыха климат.

Говоря подробнее о рекреационном потенциале региона, нельзя не отметить его уникальные природные богатства. Главным из них являются целебные минеральные воды. На сегодняшний день разведано более 130 выходов минеральных вод, а по своим физико-химическим свойствам эти воды включают в себя практически все известные мировой науке типы.

Туристская и рекреационная сфера делает свой вклад в экономику Ставропольского края и России в целом. Согласно данным краевого Министерства туризма и оздоровительных курортов, на 2019 год в Ставропольском крае насчитывается 259 туристских организаций, 121 санаторно-курортное учреждение и 382 коллективных средства размещения (гостиницы и хостелы). 
Вместе с тем, несмотря на колоссальный туристский потенциал СКФО, существуют факторы, препятствующие его полноценной реализации. Эксперты отмечают, что туризм в СКФО находится в «состоянии стагнации». Так, Кольчугина Т. А. в своём исследовании приводит исчерпывающие статистические данные, которые свидетельствуют об этом. Довольно показательным является коэффициент, выраженный отношением числа туристов, размещённых в коллективных средствах размещения (КСР) за год (в исследовании - 2017) к населению СКФО. Он составил всего 0,14 - это самый низкий показатель из всех федеральных округов.

Кроме того, развитию туристского потенциала СКФО препятствует недостаточно развитая инфраструктура, слабая пиар-компания региона в целом, имидж «неспокойного» и «небезопасного» региона, отсутствие в регионе международных гостиничных сетей, небольшое число СКР, прошедших международную аккредитацию и др.

В итоге, можно сказать, что, с одной стороны, регион СКФО имеет большой потенциал для развития в нём внутреннего и международного туризма, с другой стороны, этот потенциал остаётся во многом нереализованным, и на данный момент есть целый комплекс проблем, требующих решения.

$$
* * *
$$

1. Кавказский государственный природный биосферный заповедник [Электронный ресурс] - URL: https://kavkazzapoved.ru/about (дата обращения: 20.05.2021).

2. Кольчугина Т. А. Анализ состояния туризма в СКФО и определение точек роста его развития //Университетские чтения-2019. Материалы научно-методических чтений ПГУ. - 2019. - С. 136142.

3. Кольчугина Т. А. Классификация гидроминеральных ресурсов Кавказских Минеральных Вод // Университетские чтения - 2018. Материалы научно-методических чтений ПГУ. Пятигорск, 2018. C. 184-191.

4. О состоянии и перспективах работы туристско-рекреационного комплекса Ставропольского края. Министерство туризма и оздоровительных курортов Ставропольского края. [Электронный pecypc].

URL: http://mintourism26.ru/upload/iblock/9f6/informatsi_o_sostoyanii_i_perspektivakh_raboty_turistsko_rekr eatsionnogo_kompleksa_stavropolskogo_kr.pdf (дата обращения: 20.03.2021)

5. Регионы России социально-экономические показатели 2018. Росстат. [Электронный ресурс]. URL: https://www.gks.ru/free_doc/doc_2018/region/reg-pok18.pdf (дата обращения: 20.12.2019)

6. Реестр санаторно-курортных учреждений Ставропольского края. Министерство туризма и оздоровительных курортов Ставропольского края. [Электронный ресурс]. URL: http://mintourism26.ru/opendata/ (дата обращения: 20.03.2021)

7. Цитадель, Старый город и крепостные сооружения Дербента [Электронный ресурс] - URL: https://whc.unesco.org/ru/list/1070 (дата обращения: 20.05.2021).

\section{Зиниша О.С., Некрасова В.В., Кучеренко А.А. \\ Влияние пандемии на работу малого и среднего бизнеса и поддержка государства во времяCOVID-19}

ФГБОУ ВО «Кубанский государственный агарный университет имени И. Т. Трубилина»

(Россия, Краснодар)

doi: 10.18411/lj-06-2021-272

\section{Аннотация}

В статье рассматривается проблема влияния пандемии на работу малого и среднего бизнеса, а также представлены основные отрасли, которые наиболее пострадали от воздействия COVID-19 и основные проблемы функционирования МСП в условиях локдауна. Актуальность данной темы определена тем, что, 